\title{
Alternatives to reduce sodium in processed foods and the potential of high pressure technology
}

\author{
Fernando Morais RODRIGUES ${ }^{1 *}$, Amauri ROSENTHAL ${ }^{2}$, Júlia Hauck TIBURSKI ${ }^{1,2}$, Adriano Gomes da CRUZ ${ }^{3}$
}

\begin{abstract}
In most industrialized countries, the sodium intake exceeds the nutritional recommendations. In this sense the search for healthier foods has led the food industry to review their formulations in relation to food components such as salt, which is associated with increased risk of chronic diseases. As a result, different strategies for reducing salt levels in processed foods have been investigated. Among the technological options available, the high-pressure processing has stood out by presenting intrinsic technological advantages that can contribute to optimization of food formulations with low / reduced sodium contents. This review provides a brief overview of the key strategies and use of high pressure in the development of reduced-salt products.

Keywords: salt reduction; excessive consumption; technological options; High Pressure Processing (HPP); hypertension risk.

Practical application: Alternatives to sodium reduction in processed foods are presented in this study, and can serve as a reference source for future joint studies of research institutions, food industries, and regulatory health agencies. Although sodium chloride has relevant technological and sensory functions in food products, excess consumption may lead to the risk of cardiovascular diseases. Salt replacement by other salts and ingredients are discussed, in particular, the potential use of high pressure technology.
\end{abstract}

\section{Introduction}

Reducing salt levels in processed food has been one of the goals of the food industry (World Health Organization, 2011). Although sodium chloride is an essential nutrient for maintenance of health, excessive consumption is associated with the development of cardiovascular diseases, hypertension, neurological diseases, osteoporosis, gastric cancer, kidney disease, asthma, and obesity (Doyle \& Glass, 2010; He \& MacGregor, 2010; Wyness et al., 2012). Therefore, the World Health Organization (WHO) recommends reducing sodium in order to promote health (World Health Organization, 2011). Accordingly, there is a growing interest in producing low sodium foods. However, salt is an important ingredient in foods concerning the technological and sensorial aspects, thus characteristics such as taste and texture may be affected when it is reduced in the formulation (Desmond, 2006), influencing consumers' acceptance (Saint-Eve et al., 2009).

In Brazil, recent report has shown that most sodium source is originated from the table salt $(\mathrm{NaCl})$ (Collucci, 2013). Despite low-sodium products have been found in some markets, the production of these items with satisfactory sensory acceptance and technological performance is still a challenge (Dos Santos et al., 2015a, b; Agarwal et al., 2011; Cruz et al., 2011). Therefore, several studies (Noort et al., 2010) have been conducted to find alternatives that enable to keep the same functionality, but with partial reduction or even total elimination of sodium from formulations. Among them, processing of low sodium foods, especially meat (Aliño et al., 2009; Campagnol et al., 2012;
Ruusunen et al., 2005b) and cheese (Felicio et al., 2016; Lollo et al., 2015; Ganesan et al., 2014; Gomes et al., 2011; Grummer et al., 2013) has gained much attention.

Alternative technologies such as the use of high hydrostatic pressure (Crehan et al., 2000; Ozturk et al., 2013), replacement by sodium potassium (Aliño et al., 2010; Pojedinec et al., 2011), natural flavor enhancers (Jimenez-Maroto et al., 2013) and encapsulation of salt crystals (Noort et al., 2012) have been studied to reduce salt and/or to increase the perception of salty taste in food.

This review is intended to provide possible techniques as alternative for salt reduction in processed foods, particularly high hydrostatic pressure as a strategy for development of low sodium processed foods.

\section{Strategies for reducing salt in processed foods}

The setting targets to reduce salt levels have stimulated the search for innovative techniques and methods. It is emphasized that success in techniques to reduce salt levels in food is a multidimensional problem, involving the nature of the product, its composition, and the type of industrial processing (Ruusunen \& Puolanne, 2005a). Common approaches include reducing the amount of salt added during food processing (Aaslyng et al., 2014; Corral et al., 2013; Paulsen et al., 2014), replacement with low-sodium blends ( $\mathrm{KCl}$, $\mathrm{CaCl}_{2}$ or $\mathrm{MgCl}_{2}$ ) (Armenteros et al., 2012; Campagnol et al., 2012; 
Choi et al., 2014; Lilic et al., 2008; Paulsen et al., 2014; Wu et al., 2014; Zanardi et al., 2010), use of flavor enhancers such as monosodium glutamate (Campagnol et al., 2012; Campagnol et al., 2011a; Dos Santos et al., 2014), slight salt reduction (Liem et al., 2011), and change in the form of salt (Kilcast \& den Ridder, 2007).

\section{1 $\mathrm{NaCl}$ replaced by other salts / ingredients}

Among the substitutes for table salt $(\mathrm{NaCl})$, potassium chloride $(\mathrm{KCl})$ is the most common (He \& MacGregor, 2010). However, the replacement of salt by $\mathrm{KCl}$ in most foods must be made partially or limited to $30 \%$, since higher levels provide bitter and metallic aftertaste (Doyle \& Glass, 2010; Grummer et al., 2013; Horita et al., 2014; Toldrá \& Reig, 2011). Previous studies have shown to be possible to replace 30 to $40 \% \mathrm{NaCl}$ for $\mathrm{KCl}$ in fermented sausages (Paulsen et al., 2014). In this sense, Rodrigues et al. (2014) developed mozzarella cheese with low sodium content using salt blends. The three Mozzarella cheese formulations were: Formulation A (control) produced only with $\mathrm{NaCl}$ ( $0 \%$ sodium reduction), formulation B (30\% sodium reduction), and formulation C (54\% sodium reduction). Each formulation was produced using a salt blend consisting of $\mathrm{NaCl}, \mathrm{KCl}$ and monosodium glutamate at different concentrations. They concluded that the salt levels did not have a negative impact, and the use of the salt blend is a viable alternative for the production of mozzarella, with a reduction of up to $54 \%$ sodium while maintaining acceptable the perception of salty taste. Wu et al. (2014) evaluated the partial replacement of $\mathrm{NaCl}$ for $\mathrm{KCl}$ in bacon samples. Three salt treatments were studied: I (100\% NaCl), II (60\% NaCl and 40\% KCl), and III (30\% $\mathrm{NaCl}$ and $70 \% \mathrm{KCl})$. In general, the sensory results indicate to be possible to reduce $40 \% \mathrm{NaCl}$ without adverse effects on sensory characteristics such as taste and texture attributes, and did not significantly influence the proteolysis. Choi et al. (2014) studied the combined effect of sodium chloride $(\mathrm{NaCl})$ with potassium lactate (R-lactide) and calcium ascorbate (Ca-ascorbate) on the physicochemical and sensory characteristics of low salt sausages $(1.2 \% \mathrm{NaCl})$. Sausages produced with $40 \%$ substitution of $\mathrm{NaCl}$, $30 \% \mathrm{~K}$-lactate and 10\% Ca-ascorbate exhibited water retention capacity, texture properties and sensory characteristics similar to the control. The authors suggested the use of these salt blends to reduce $\mathrm{NaCl}$ content in meat products. The effect of the partial substitution of $\mathrm{NaCI}$ for $\mathrm{KCI}$ in probiotic Akawi cheese (fresh cheese) was investigated by Ayyash et al. (2012) during 30 days of storage at $4{ }^{\circ} \mathrm{C}$. The chemical composition, proteolytic activity, and sensory analysis were conducted to determine the effects of substitution. The results showed no significant differences in the chemical composition and sensory attributes of the cheese, including creaminess, bitter taste, salty taste, and sour taste. A decrease in the growth of probiotic bacteria was observed, depending on the microorganism species used (Streptococcus thermophilus, Lactobacillus casei, Lactobacillus acidophilus). In Minas fresh cheese, the replacement of $\mathrm{NaCl}$ by 25,50 , and $75 \% \mathrm{KCl}$ showed differences in chemical composition, as well as increased proteolytic activity and decreased hardness during storage. Furthermore, the sensory study indicated the feasibility of partial substitution of $25 \% \mathrm{NaCl}$ by $\mathrm{KCl}$ (Gomes et al., 2011). Salts without chloride ions as $\mathrm{Na}-\mathrm{K}$-lactate and lactate are examples of ingredients used to compensate for changes in salty taste and lower antimicrobial effect in low sodium meat products (Doyle \& Glass, 2010).

\subsection{Flavor enhancers}

Flavor enhancers such as monosodium glutamate (MSG), disodium inosinate (IMP), yeast extract and hydrolyzed vegetable protein (HVP) extend the perception of salty taste and can reduce the sodium content in the final product by $40 \%$ (Wallis \& Chapman, 2012). Enhancers act by increasing the flavor perception, due to activation of umami taste receptors (McGough et al., 2012). Dos Santos et al. (2014) produced fermented sausages with two levels of substitution of $\mathrm{NaCI}$ by $\mathrm{KCI}$, combined with monosodium glutamate, disodium inosinate, disodium guanylate and the amino acids lysine, and taurine. The color values $\left(\mathrm{L}^{*}, \mathrm{a}^{\star}, \mathrm{b}^{\star}\right)$ and texture profiles were also examined. The authors suggested that $50 \%$ replacement of $\mathrm{NaCl}$ with $\mathrm{KCl}$ and the addition of flavor enhancers produced fermented cooked sausages with suitable physicochemical and sensory qualities. The addition of such compounds in suitable levels was sufficient to eliminate the defects caused by the replacement of $50 \%$ and $75 \% \mathrm{NaCl}$ by $\mathrm{KCl}$, thus resulting in a sodium reduction of $68 \%$ in the sausages. Grummer et al. (2013) investigated the partial substitution of $\mathrm{NaCl}$ by $\mathrm{KCl}$ in Cheddar cheese. To reduce the taste of bitter and metallic caused by the use of $\mathrm{KCl}$, flavour enhancers were used, due to their ability to reduce these undesirable sensory effects. The cheese was processed using $60 \% \mathrm{NaCl}, 40 \% \mathrm{KCl}$ and flavor enhancers (hydrolyzed vegetable protein/yeast extract). The study showed that Cheddar cheese with low-sodium obtained from the partial replacement of $\mathrm{NaCl}$ by $\mathrm{KCl}$ can result in good consumer acceptance due to adequate perception of salty taste and low bitterness. The use of flavor enhancers lead to mixed results. According to some judges, those compounds influenced the taste in a positive way, while for others they resulted in a significant reduction in the liking score. McGough et al. (2012) investigated quality and sensory impacts associated with partial replacement and/or reduction of normally added $\mathrm{NaCl}$ using a natural flavor enhancer (NFE) in frankfurters. Different levels of natural flavor enhancer, $\mathrm{NaCl}$, and $\mathrm{KCl}$ were used to produce the sausages. The natural taste enhancer contained the following ingredients: water, soybeans, wheat, salt, and alcohol. As a result the authors suggested that the use of enhancer allowed a reduction of $20 \% \mathrm{NaCl}$ with no adverse effects on the sensory quality of the product. Conversely, when the partial substitution of $\mathrm{NaCI}$ for KCI combined with the use of enhancer was used, the reduction of $\mathrm{NaCl}$ was $35 \%$ without compromising the sensory attributes of the product. Campagnol et al. (2011b) investigated the replacement of 50\% $\mathrm{NaCl}$ by $\mathrm{KCl}$ and addition of the amino acids and flavor enhancers in fermented sausages. The $\mathrm{NaCl}$ concentration was reduced from $2.5 \%$ to $1.25 \%$. For the treatments with $\mathrm{NaCl}$ replaced by $\mathrm{KCl}$, the amino acids lysine and taurine were added, in addition to the flavor enhancers (50\% disodium inosinate and 50\% disodium guanylate). Although the results of this study have shown that replacing $50 \%$ of $\mathrm{NaCl}$ by $\mathrm{KCl}$ did not cause changes in the fermentation and dehydration of sausages, the sensory quality was negatively affected. However, using the amino acid lysine at a concentration of $1 \%$ with disodium inosinate $(300 \mathrm{mg} / \mathrm{kg})$ and disodium guanylate $(300 \mathrm{mg} / \mathrm{kg})$, the sensory defects resulting from substitution of $50 \% \mathrm{NaCl}$ by $\mathrm{KCl}$ were suppressed. Despite these ingredients have provided improvements in flavor, they are associated with negative health aspects (Insawang et al., 2012). 
The use of MSG, for example, is related to health problems like headache, hyperactivity and metabolic changes that may result in serious disorders (Kilcast \& den Ridder, 2007). The use of yeast and hydrolyzed protein extracts can mask flavors in low sodium meat products, but has limited use to levels around $40 \%$ due to undesirable flavor (meat flavor) in some foods, causing rejection by consumers. Campagnol et al. (2011a) investigated the replacement of $25 \%$ and $50 \% \mathrm{NaCl}$ by $\mathrm{KCl}$ in fermented sausages. The concentrations of $1 \%$ and $2 \%$ of commercial yeast extract produced from Saccharomyces cerevisiae were added to the fermented sausages with reduced sodium content. The results indicated that substitution of $\mathrm{NaCI}$ for $\mathrm{KCI}$ did not significantly affect the physicochemical or microbiological characteristics. Regarding the sensory characteristics, the product had a negative score for the attribute flavor when substituted at $50 \% \mathrm{NaCl}$, and the use of yeast extract at a concentration of $2 \%$ contributed to the suppression of sensory defects caused by the addition of $\mathrm{KCl}$.

Reducing sodium in the production of white bread was investigated by (Jimenez-Maroto et al., 2013). Bread samples were prepared using a fermented soy product as the main sodium source (natural flavor enhancer-NFE) to replace table salt. The white bread samples were made using table salt $(\mathrm{NaCl})$, and the replacement of $25 \%, 50 \%$ and $100 \%$ of sodium by NFE. The replacement of table salt by NFE resulted in increased perception of salty taste. The authors suggested a $40 \%$ sodium reduction in white bread, and a good sensory acceptability (flavor, taste, texture and aroma) was observed with $25 \%$ salt reduction.

\subsection{Structure of salt crystals $(\mathrm{NaCl})$ and slight salt reduction}

The perception of the salty taste is related to the physical shape of salt crystals (Barringer, 2006; Desmond, 2006; Wallis \& Chapman, 2012). According to Rama et al. (2013), salt crystal size is fundamental because lower salt crystals are more easily diffused into the product, leading to a greater perception of salty taste. It is believed that the perception of salty taste occurs due to the solubility of sodium chloride in saliva, resulting in increased perception of such attribute. In recent years, companies such as Morton and Cargill have optimized the physical form of the salt crystals $(\mathrm{NaCl})$ in order to make them more soluble (Desmond, 2006). Johnson et al. (2008) studied the effect of the size and shape of $\mathrm{NaCl}$ particles to prepare a seasoning. These authors found that as the size of salt particles decreased $(20 \mu \mathrm{m})$, their diffusion into the food matrix increased, resulting in higher perception of salty taste by assessors. Another technique that has been used is a gradual reduction of the content during food production (Liem et al., 2011). This technique consists of making the consumer gradually accustomed to low salt foods, without necessarily noticing that the food is less salty. Through this technique, some manufacturers have managed reductions of up to $50 \%$ salt in some rice and corn based products (Wallis \& Chapman, 2012). Bobowski et al. (2015) investigated the gradual salt reduction compared to the abrupt salt reduction. Eighty-three subjects participated in a three-part study: an initial taste test, a 16-week longitudinal study, and a final taste test. At the initial and final taste tests, subjects indicated liking of tomato juice at four salt concentrations ranging from $136 \mathrm{mg}$ sodium/serving (low sodium) to $640 \mathrm{mg}$ sodium/serving (comparable to a commercially available product). To create two groups for the 16-week study, subjects were balanced for motivation to reduce dietary salt intake, and hedonic sensitivity to salt (the difference in liking between the highest and lowest salt concentrations in tomato juice served at the initial taste test). One group received juice abruptly reduced in salt at week 4 to a target low sodium level; the second group received juice gradually reduced in salt. The results showed that the gradual reduction of salt was more effective than the abrupt reduction of the salt. Subjects with low hedonic sensitivity responded favorably to both salt reduction strategies. The results showed that the gradual salt reduction was more effective than the abrupt salt reduction. Subjects with low hedonic sensitivity responded favorably to both salt reduction strategies. However, subjects with high sensitivity hedonic disliked the juice and salt reduction at some point during the study, regardless of the strategy.

\subsection{Alternative technology to reduce sodium in foods: High pressure (HP)}

High-pressure processing (HPP) is a non-thermal preservation technique that inactivates harmful pathogens and vegetative spoilage microorganisms by using pressure rather than heat. HPP uses intense pressure (about $400-600 \mathrm{MPa}$ or $58,000-87,000 \mathrm{psi}$ ) and mild process temperatures $\left(<45^{\circ} \mathrm{C}\right)$, allowing most foods to be preserved with minimal effects on taste, texture, appearance, and nutritional value (Cruz et al., 2010). The positive effects of high pressure in processed food such as meat and dairy products as regards the sensory quality and technological attributes have been widely reported including in vivo studies (Wang et al., 2015). However, the possibility of the positive contribution of HPP to the development of low sodium foods remains almost unexplored.

\section{Meat products}

Meat and meat products are considered the second largest sodium contributor in diet, followed by bakery products. For some time, the meat industry has used the high hydrostatic pressure to improve their products (Vercammen et al., 2011). Its use in meat confers microbiological stability and changes in the functional properties of proteins, such as absorption and water retention, improving emulsifying ability, and solubilizing myofibrillar proteins (Iwasaki et al., 2006).

Some studies have been conducted to investigate the interaction between high pressure and salt levels in the functional properties of meat products (Grossi et al., 2012). High pressure processing has excellent potential as a complementary technology to reduce the salt content and increase the shelf life of the product. In fact, O'Flynn et al. (2014) compared the effect of pork pressurization in the preparation of low sodium sausages. The treatment consisted of subjecting the sample to different salt levels $(0.5,1.0,1.5,2.0$, and $2.5 \%)$ at $150 \mathrm{MPa} / 5 \mathrm{~min}$. Salt levels below $1.5 \%$ resulted in negative effects on color, texture, juiciness and firmness of the products. However, the results indicate that the treatment at $150 \mathrm{MPa}$ and salt levels above $2 \%$ have potential for manufacturing sausages with no negative effects on the sensory attributes. 
The development of low sodium meat products suggests the existence of a multifactorial process, with interactions between HPP parameters (pressure, temperature and time), salt level, and concentration of additives (polyphosphates), affecting the functional properties of meat products (O’Flynn et al., 2014; Villamonte et al., 2013). Research conducted by Villamonte et al. (2013) studied high pressure processing in pork $\left(350 \mathrm{MPa} / 6\right.$ minutes $\left./ 20^{\circ} \mathrm{C}\right)$, associated with the use of salt (1.5-3.0\%) and phosphate (0.25-0.5\%), and found that HP yielded a synergistic effect between texture and water retention capacity, suggesting the possibility of development of low sodium meat products without addition of polyphosphates. Speroni et al. (2014) investigated the effect of $\mathrm{HP}\left(200 \mathrm{MPa}\right.$ and $\left.300 / 5 \mathrm{~min} / 5^{\circ} \mathrm{C}\right)$, concentration of sodium tripolyphosphate (STPP) and sodium chloride $(\mathrm{NaCl})$ on the production of burgers. The burgers were prepared with the following composition: $80 \%$ lean meat (w/w), $10 \%$ water $(w / w) ; 0,1$, or $2 \%$ sodium chloride, and/or $0,0.25$ or $0.5 \%$ sodium tripolyphosphate, and the percentage of meat has been modified according to salt levels. Changes in texture and technological properties of the reduced-salt meat products were observed, depending on the type of salt, concentration levels, and pressure applied (200 to $300 \mathrm{MPa}$ ). Other authors have investigated the effect of high pressure on the commercial cured meat products (Clariana et al., 2011) and in all cases (dry cured loin and cured ham) the salinity levels increased after high pressure application (> 500 MPa). Since an increase in the salt content after pressurization was not observed, the increase in the salty taste perception cannot be related to higher salt contents. Thus, it was suggested that high pressure has changed the interactions between sodium ions and proteins, resulting in the release of $\mathrm{Na}+$ and making them more accessible to the taste cells (Clariana et al., 2011). Thus, there is evidence that high pressure can provide a natural increase saltiness, thus being an alternative for salt reduction.

The use of unconventional ingredients in meat based formulations such as fiber and starch has also been mentioned as potential alternative for the synergistic action of HPP on low sodium meat products. Grossi et al. (2012) investigated the effect of high hydrostatic pressure $(400,600$, and $800 \mathrm{MPa})$ combined with the use of ingredients such as carrot and potato starch fibers in pork sausages with low salt content (1.2 and $1.8 \% \mathrm{w} / \mathrm{w})$. HPP has also proven to be a promising technique to improve salty taste in cured hams pressurized at 300, 600 and $900 \mathrm{MPa} / 300 \mathrm{~s}$ (Picouet et al., 2012). The authors observed an increase in both water retention capacity and mobility of sodium confirmed by nuclear magnetic resonance and transmission electron microscopy, which evidenced that sodium was more uniformly distributed in the product. Similar results were observed in frozen hams in two production stages (at the beginning or end of maturation) (Serra et al., 2007). The use of HPP (400 MPa to $600 \mathrm{MPa} / 10 \mathrm{~min}$ ) led to a decrease in salt absorption, when compared to non-pressurized hams, probably due to proteins denaturation and increased proteolytic activity. Crehan et al. (2000) produced sausages with salt levels of $1.5 \%$ and 2.5 subjected to pressure of 150 to $300 \mathrm{MPa}$. The samples were evaluated for emulsion stability, color, and sensory characteristics and compared with the control (non-pressurized treatment). The results demonstrated that the texture, protein functionality, and the saltiness perception was improved in sausages made with less salt and subjected to high hydrostatic pressure (150 MPa). Ferrini et al. (2012) reported that the reduction or replacement $\mathrm{NaCl}$ by $\mathrm{KCl}$ or $\mathrm{K}$-lactate combined with a process of rapid drying and high pressure enabled the production of low-sodium dry cured meat, with no effects on appearance and with less microbiological risk. Fulladosa et al. (2012) stated that the use of K-lactate combined with high pressure treatment $(600 \mathrm{MPa})$ led to an additional reduction in microbial counts and adhesiveness and an increase in pink color, brightness, hardness and salinity of the products.

\section{Dairy product: cheese}

The high pressure applied to the production of dairy products has received considerable attention in recent years (Trujillo et al., 2002).

Among dairy products, cheese represents a decisive contribution to sodium intake in countries with different socio-economic levels (Agarwal et al., 2011; Moshfegh et al., 2012; Ni Mhurchu et al., 2011). The consumption of cheese varies broadly in the world and is the main growth in the dairy product industry, along with fermented products. Considering that the portion size and frequency of cheese consumption can vary among consumers, these results are quite alarming from a public health point of view, and contribute significantly to the sodium intake by the population (Felicio et al., 2013). The situation becomes more aggravating in the category of processed cheese, in which sodium-based emulsifying salts are needed for the melting step, being intrinsic to the product. In this context, as well as meat products, there is a need to recast the cheese formulations to meet the recommendations of health agencies.

Previous studies on the production of high-pressure treated cheeses have focused on the coagulation properties. High pressure can improve milk coagulation properties, reduce clotting time and increase gel firmness (Zamora et al., 2012). The application of high pressure to the milk prior to cheese manufacture have been scientifically explored and, when combined with manufacturing protocols, it can produce high quality cheese without the health risks caused by pathogenic contamination, such as Salmonella spp. and Listeria monocytogenes (Martínez-Rodríguez et al., 2012). HPP of milk affects coagulation and cheesemaking properties indirectly through a number of effects on milk proteins, including the reduction in the size of casein micelles and denaturation of $\beta$-lactoglobulin, probably followed by interaction with micellar $\kappa$-casein (O’Reilly et al., 2001). Voigt et al. (2012) observed that high pressure treatment at $600 \mathrm{MPa}$ milk prior to Cheddar cheese production reduced the initial microbial load, and increased proteolysis during ripening. Trujillo et al. (2002) have reported the potential changes induced by high pressure in dairy products. The use of high pressure for manufacture of cheese with low/reduced sodium is not a common practice in literature and unlike meat products, few reports are available. However, the results have shown the potential of HPP for this purpose. In fact, HHP can alter water and salt distribution in the cheese matrix, due to the conversion of free water into proteinbound water and a reduced compliance of the cheese matrix during pressure brining (Martínez-Rodríguez et al., 2012). Salt 
addition increases the ionic strength in cheese, which promotes increased solvation of proteins, thus altering protein interactions. Such increased protein-to-water interactions cause partial relaxation of the protein matrix, which becomes more hydrated and swells. As an immediate consequence, the perception of salty taste in the cheese matrix can increase even with a smaller amount of salt added to the formulation because of a possible more homogeneous distribution in the product matrix. As also reported for meat products, the manufacture of cheese with low / reduced sodium using HPP is a multifactorial process, with interactions between HPP conditions (time, temperature, and pressure level), type of cheese (fresh or ripened), and salt concentration, which was evidence by a recent study on Cheddar cheese Ozturk et al. (2013) formulated with four sodium levels (regular, reduced, low, and none; 5.3, 2.5, 1.9, and $0.2 \%$ sodium chloride) and treated by high pressure ( $405 \mathrm{MPa} / 3 \mathrm{~min})$. Pressure treated and non-treated cheeses containing similar $\mathrm{NaCl}$ levels showed similar sensory profiles with regards to sour taste, salty taste, and bitterness.

\section{Conclusions}

The main sodium source in diet is the table salt $(\mathrm{NaCl})$. Although adequate sodium intake is necessary for the proper functioning of the body, the consumption of excessive amounts of sodium is associated with diseases such as hypertension. Studies have been conducted to promote the consumption of low sodium foods, thus some strategies for sodium reduction in processed foods were presented in this review. Alternatively, there are a number of techniques that have or can be implemented in food manufacturing in various sectors, especially the high-pressure processing. However, challenges in the development of food products on a commercial scale indicate that further studies to optimize the sensory and technological properties of the salt reduced products should be performed. The joint work of research institutions, food industries and regulatory health agencies, especially when considering the consumer, can bring positive responses towards the salt reduction target.

\section{References}

Aaslyng, M. D., Vestergaard, C., \& Koch, A. G. (2014). The effect of salt reduction on sensory quality and microbial growth in hotdog sausages, bacon, ham and salami. Meat Science, 96(1), 47-55. http:// dx.doi.org/10.1016/j.meatsci.2013.06.004. PMid:23896136.

Agarwal, S., McCoy, D., Graves, W., Gerard, P. D., \& Clark, S. (2011). Sodium content in retail Cheddar, Mozzarella, and process cheeses varies considerably in the United States. Journal of Dairy Science, 94(3), 1605-1615. http://dx.doi.org/10.3168/jds.2010-3782. PMid:21338828.

Aliño, M., Grau, R., Fuentes, A., \& Barat, J. M. (2010). Influence of low-sodium mixtures of salts on the post-salting stage of dry-cured ham process. Journal of Food Engineering, 99(2), 198-205. http:// dx.doi.org/10.1016/j.jfoodeng.2010.02.020.

Aliño, M., Grau, R., Toldrá, F., Blesa, E., Pagán, M. J., \& Barat, J. M. (2009). Influence of sodium replacement on physicochemical properties of dry-cured loin. Meat Science, 83(3), 423-430. http:// dx.doi.org/10.1016/j.meatsci.2009.06.022. PMid:20416693.

Armenteros, M., Aristoy, M.-C., Barat, J. M., \& Toldrá, F. (2012). Biochemical and sensory changes in dry-cured ham salted with partial replacements of $\mathrm{NaCl}$ by other chloride salts. Meat Science,
90(2), 361-367. http://dx.doi.org/10.1016/j.meatsci.2011.07.023. PMid:21871742.

Ayyash, M. M., Sherkat, F., \& Shah, N. P. (2012). The effect of $\mathrm{NaCl}$ substitution with $\mathrm{KCl}$ on Akawi cheese: chemical composition, proteolysis, angiotensin-converting enzyme-inhibitory activity, probiotic survival, texture profile, and sensory properties. Journal of Dairy Science, 95(9), 4747-4759. http://dx.doi.org/10.3168/ jds.2011-4940. PMid:22916878.

Barringer, S. A. (2006). Coating snack foods. In Y. H. Hui (Ed.), Handbook of food science, technology and engineering (pp. 169-1699). New York: CRC Press.

Bobowski, N., Rendahl, A., \& Vickers, Z. (2015). A longitudinal comparison of two salt reduction strategies: acceptability of a low sodium food depends on the consumer. Food Quality and Preference, 40(Part B), 270-278. http://dx.doi.org/10.1016/j.foodqual.2014.07.019

Campagnol, P. C. B., Santos, B. A., Morgano, M. A., Terra, N. N., \& Pollonio, M. A. R. (2011b). Application of lysine, taurine, disodium inosinate and disodium guanylate in fermented cooked sausages with $50 \%$ replacement of $\mathrm{NaCl}$ by KCl. Meat Science, 87(3), 239-243. http://dx.doi.org/10.1016/j.meatsci.2010.10.018. PMid:21067870.

Campagnol, P. C. B., Santos, B. A., Terra, N. N., \& Pollonio, M. A. R. (2012). Lysine, disodium guanylate and disodium inosinate as flavor enhancers in low-sodium fermented sausages. Meat Science, 91(3), 334-338. http://dx.doi.org/10.1016/j.meatsci.2012.02.012. PMid:22391056.

Campagnol, P. C. B., Santos, B. A., Wagner, R., Terra, N. N., \& Pollonio, M. A. R. (2011a). The effect of yeast extract addition on quality of fermented sausages at low $\mathrm{NaCl}$ content. Meat Science, 87(3), 290-298. http://dx.doi.org/10.1016/j.meatsci.2010.11.005. PMid:21123002.

Choi, Y. M., Jung, K. C., Jo, H. M., Nam, K. W., Choe, J. H., Rhee, M. S., \& Kim, B. C. (2014). Combined effects of potassium lactate and calcium ascorbate as sodium chloride substitutes on the physicochemical and sensory characteristics of low-sodium frankfurter sausage. Meat Science, 96(1), 21-25. http://dx.doi.org/10.1016/j.meatsci.2013.06.022. PMid:23896133.

Clariana, M., Guerrero, L., Sárraga, C., Díaz, I., Valero, Á., \& GarcíaRegueiro, J. A. (2011). Influence of high pressure application on the nutritional, sensory and microbiological characteristics of sliced skin vacuum packed dry-cured ham. Effects along the storage period. Innovative Food Science \& Emerging Technologies, 12(4), 456-465. http://dx.doi.org/10.1016/j.ifset.2010.12.008.

Collucci, C. (2013, July 21). Um quarto do sódio ingerido no país vem de comida processada. Folha de São Paulo. Retrieved from http:// www1.folha.uol.com.br/equilibrioesaude/2013/07/1314065-umquarto-do-sodio-ingerido-no-brasil-vem-de-comida-processada.shtml

Corral, S., Salvador, A., \& Flores, M. (2013). Salt reduction in slow fermented sausages affects the generation of aroma active compounds. Meat Science, 93(3), 776-785. http://dx.doi.org/10.1016/j. meatsci.2012.11.040. PMid:23261539.

Crehan, C. M., Troy, D. J., \& Buckley, D. J. (2000). Effects of salt level and high hydrostatic pressure processing on frankfurters formulated with 1.5 and $2.5 \%$ salt. Meat Science, 55(1), 123-130. http://dx.doi. org/10.1016/S0309-1740(99)00134-5. PMid:22060912.

Cruz, A. G., Faria, J. A. F., Pollonio, M. A. R., Bolini, H. M. A., Celeghini, R. M. S., Granato, D., \& Shah, N. P. (2011). Cheeses with reduced sodium content: Effects on functionality, public health benefits and sensory properties. Trends in Food Science \& Technology, 22(6), 276-291. http://dx.doi.org/10.1016/j.tifs.2011.02.003.

Cruz, A. G., Faria, J. A. F., Saad, S. M. I., Bolini, H. M. A., Sant’Ana, A. S., \& Cristianini, M. (2010). High pressure processing and pulsed 
electric fields: potential use in probiotic dairy foods processing. Trends in Food Science and Technology, 21(10), 483-493.

Desmond, E. (2006). Reducing salt: a challenge for the meat industry. Meat Science, 74(1), 188-196. http://dx.doi.org/10.1016/j. meatsci.2006.04.014. PMid:22062728.

Dos Santos, B. A., Campagnol, P. C. B., Cruz, A. G., Morgano, M. A., Wagner, R., \& Pollonio, M. A. R. (2015a). Is there a potential consumer market for low-sodium fermented sausages? Journal of Food Science, 80(5), S1093-S1099.

Dos Santos, B. A., Campagnol, P. C. B., Cruz, A. G., Galvão, M. T. E. L., Monteiro, R. A., Wagner, R., \& Pollonio, M. A. R. (2015b). Check all that apply and free listing to describe the sensory characteristics of low sodium dry fermented sausages: comparison with trained panel. Food Research International, 76(Part 3), 725-734.

Dos Santos, B. A., Campagnol, P. C. B., Morgano, M. A., \& Pollonio, M. A. R. (2014). Monosodium glutamate, disodium inosinate, disodium guanylate, lysine and taurine improve the sensory quality of fermented cooked sausages with $50 \%$ and $75 \%$ replacement of $\mathrm{NaCl}$ with KCl. Meat Science, 96(1), 509-513. http://dx.doi.org/10.1016/j. meatsci.2013.08.024. PMid:24008059.

Doyle, M. E., \& Glass, K. A. (2010). Sodium reduction and its effect on food safety, food quality, and human health. Comprehensive Reviews in Food Science and Food Safety, 9(1), 44-56. http://dx.doi. org/10.1111/j.1541-4337.2009.00096.x.

Felicio, T. L., Esmerino, E. A., Cruz, A. G., Nogueira, L. C., Raices, R. S. L., Deliza, R., Bolini, H. M., \& Pollonio, M. A. (2013). Cheese. What is its contribution to the sodium intake of Brazilians? Appetite, 66, 84-88. http://dx.doi.org/10.1016/j.appet.2013.03.002. PMid:23500416.

Felicio, T. L., Esmerino, E. A., Vidal, V. A. S., Cappato, L. P., Garcia, R. K. A., Cavalcanti, R. N., Freitas, M. Q., Conte, C. A. Jr., Padilha, M. C., Silva, M. C., Raices, R. S. L., Arellano, D. B., Bollini, H. M. A., Pollonio, M. A. R., \& Cruz, A. G. (2016). Physico-chemical changes during storage and sensory acceptance of low sodium probiotic Minas cheese added with arginine. Food Chemistry, 196(1), 628-637.

Ferrini, G., Comaposada, J., Arnau, J., \& Gou, P. (2012). Colour modification in a cured meat model dried by Quick-Dry-Slice process $^{\oplus}$ and high pressure processed as a function of $\mathrm{NaCl}, \mathrm{KCl}$, $\mathrm{K}$-lactate and water contents. Innovative Food Science \& Emerging Technologies, 13, 69-74. http://dx.doi.org/10.1016/j.ifset.2011.09.005.

Fulladosa, E., Sala, X., Gou, P., Garriga, M., \& Arnau, J. (2012). K-lactate and high pressure effects on the safety and quality of restructured hams. Meat Science, 91(1), 56-61. http://dx.doi.org/10.1016/j. meatsci.2011.12.006. PMid:22226361.

Ganesan, B., Brown, K., Irish, D. A., Brothersen, C., \& McMahon, D. J. (2014). Manufacture and sensory analysis of reduced-and low-sodium Cheddar and Mozzarella cheeses. Journal of Dairy Science, 97(4), 1970-1982. http://dx.doi.org/10.3168/jds.2013-7443. PMid:24485677.

Gomes, A. P., Cruz, A. G., Cadena, R. S., Celeghini, R. M. S., Faria, J. A. F., Bolini, H. M. A., Pollonio, M. A., \& Granato, D. (2011). Manufacture of low-sodium Minas fresh cheese: effect of the partial replacement of sodium chloride with potassium chloride. Journal of Dairy Science, 94(6), 2701-2706. http://dx.doi.org/10.3168/jds.20103774. PMid:21605739.

Grossi, A., Søltoft-Jensen, J., Knudsen, J. C., Christensen, M., \& Orlien, V. (2012). Reduction of salt in pork sausages by the addition of carrot fibre or potato starch and high pressure treatment. Meat Science, 92(4), 481-489. http://dx.doi.org/10.1016/j.meatsci.2012.05.015. PMid:22682686.

Grummer, J., Bobowski, N., Karalus, M., Vickers, Z., \& Schoenfuss, T. (2013). Use of potassium chloride and flavor enhancers in low sodium Cheddar cheese. Journal of Dairy Science, 96(3), 1401-1418. http://dx.doi.org/10.3168/jds.2012-6057. PMid:23332837.

He, F. J., \& MacGregor, G. A. (2010). Reducing population salt intake worldwide: from evidence to implementation. Progress in Cardiovascular Diseases, 52(5), 363-382. http://dx.doi.org/10.1016/j. pcad.2009.12.006. PMid:20226955.

Horita, C. N., Messias, V. C., Morgano, M. A., Hayakawa, F. M., \& Pollonio, M. A. R. (2014). Textural, microstructural and sensory properties of reduced sodium frankfurter sausages containing mechanically deboned poultry meat and blends of chloride salts. Food Research International, 66, 29-35. http://dx.doi.org/10.1016/j. foodres.2014.09.002.

Insawang, T., Selmi, C., Cha'on, U., Pethlert, S., Yongvanit, P., Areejitranusorn, P., Boonsiri, P., Khampitak, T., Tangrassameeprasert, R., Pinitsoontorn, C., Prasongwattana, V., Gershwin, M. E., \& Hammock, B. D. (2012). Monosodium glutamate (MSG) intake is associated with the prevalence of metabolic syndrome in a rural Thai population. Nutrition \& Metabolism, 9, 1-6. http://dx.doi. org/10.1186/1743-7075-9-50. PMid:22681873.

Iwasaki, T., Noshiroya, K., Saitoh, N., Okano, K., \& Yamamoto, K. (2006). Studies of the effect of hydrostatic pressure pretreatment on thermal gelation of chicken myofibrils and pork meat patty. Food Chemistry, 95(3), 474-483. http://dx.doi.org/10.1016/j.foodchem.2005.01.024.

Jimenez-Maroto, L. A., Sato, T., \& Rankin, S. A. (2013). Saltiness potentiation in white bread by substituting sodium chloride with a fermented soy ingredient. Journal of Cereal Science, 58(2), 313-317. http://dx.doi.org/10.1016/j.jcs.2013.06.001.

Johnson, C., Jensen, M., Schilmoeller, L., \& Smith, G. (2008). Seasoning and method for seasoning a food product utilizing small particle sea salt. Google Patents. Retrieved from http://www.google.com/ patents/WO2008039453A2?cl=en

Kilcast, D., \& den Ridder, C. (2007). Sensory issues in reducing salt in food products. In D. Kilcast \& F. Angus (Eds.), Reducing salt in foods: practical strategies (pp. 201-220). Cambridge: Woodhead Publishing.

Liem, D. G., Miremadi, F., \& Keast, R. (2011). Reducing sodium in foods: the effect on flavor. Nutrients, 3(6), 694-711. http://dx.doi. org/10.3390/nu3060694. PMid:22254117.

Lilic, S., Matekalo-Sverak, V., \& Borovic, B. (2008). Possibility of replacement of sodium chloride by potassium chloride in cooked sausages: sensory characteristics and health aspects. Biotechnology in Animal Husbandry, 24(1-2), 133-138. http://dx.doi.org/10.2298/ BAH0802133L.

Lollo, P. C. B., Morato, P. N., Moura, C. S., Almada, C. N., Feliciom T. L., Esmerino, E. A., Barros, M. E., Amaya-Farfan, J., Sant’Ana, A. S., Raices, R. R. S., Silva, M. C., \& Cruz, A. G. (2015). Hypertension parameters are attenuated by the continuous consumption of probiotic Minas cheese. Food Research International, 76(Part 3), 611-617.

Martínez-Rodríguez, Y., Acosta-Muñiz, C., Olivas, G. I., GuerreroBeltrán, J., Rodrigo-Aliaga, D., \& Sepúlveda, D. R. (2012). High hydrostatic pressure processing of cheese. Comprehensive Reviews in Food Science and Food Safety, 11(4), 399-416. http://dx.doi. org/10.1111/j.1541-4337.2012.00192.x.

McGough, M. M., Sato, T., Rankin, S. A., \& Sindelar, J. J. (2012). Reducing sodium levels in frankfurters using a natural flavor enhancer. Meat Science, 91(2), 185-194. http://dx.doi.org/10.1016/j. meatsci.2012.01.018. PMid:22330943.

Moshfegh, A., Holden, J., Cogswell, M., Kuklina, E., Patel, S., Gunn, J., Gillespie, C., Hong, Y., Merritt, R., \& Galuska, D. A. (2012). Vital signs: food categories contributing the most to sodium consumptionUnited States, 2007-2008. Morbidity and Mortality Weekly Report, 61(5), 92-98. PMid:22318472. 
Ni Mhurchu, C., Capelin, C., Dunford, E. K., Webster, J. L., Neal, B. C., \& Jebb, S. A. (2011). Sodium content of processed foods in the United Kingdom: analysis of 44,000 foods purchased by 21,000 households. The American Journal of Clinical Nutrition, 93(3), 594-600. http:// dx.doi.org/10.3945/ajcn.110.004481. PMid:21191142.

Noort, M. W. J., Bult, J. H. F., \& Stieger, M. (2012). Saltiness enhancement by taste contrast in bread prepared with encapsulated salt. Journal of Cereal Science, 55(2), 218-225. http://dx.doi.org/10.1016/j. jcs.2011.11.012.

Noort, M. W. J., Bult, J. H. F., Stieger, M., \& Hamer, R. J. (2010). Saltiness enhancement in bread by inhomogeneous spatial distribution of sodium chloride. Journal of Cereal Science, 52(3), 378-386. http:// dx.doi.org/10.1016/j.jcs.2010.06.018.

O’Flynn, C. C., Cruz-Romero, M. C., Troy, D., Mullen, A. M., \& Kerry, J. P. (2014). The application of high-pressure treatment in the reduction of salt levels in reduced-phosphate breakfast sausages. Meat Science, 96(3), 1266-1274. http://dx.doi.org/10.1016/j.meatsci.2013.11.010. PMid:24334049.

O’Reilly, C. E., Kelly, A. L., Murphy, P. M., \& Beresford, T. P. (2001). High pressure treatment: applications in cheese manufacture and ripening. Trends in Food Science \& Technology, 12(2), 51-59. http:// dx.doi.org/10.1016/S0924-2244(01)00060-7.

Ozturk, M., Govindasamy-Lucey, S., Jaeggi, J. J., Johnson, M. E., \& Lucey, J. A. (2013). The influence of high hydrostatic pressure on regular, reduced, low and no salt added Cheddar cheese. International Dairy Journal, 33(2), 175-183. http://dx.doi.org/10.1016/j.idairyj.2013.01.008.

Paulsen, M. T., Nys, A., Kvarberg, R., \& Hersleth, M. (2014). Effects of $\mathrm{NaCl}$ substitution on the sensory properties of sausages: temporal aspects. Meat Science, 98(2), 164-170. http://dx.doi.org/10.1016/j. meatsci.2014.05.020. PMid:24960637.

Picouet, P. A., Sala, X., Garcia-Gil, N., Nolis, P., Colleo, M., Parella, T., \& Arnau, J. (2012). High pressure processing of dry-cured ham: ultrastructural and molecular changes affecting sodium and water dynamics. Innovative Food Science \& Emerging Technologies, 16, 335-340. http://dx.doi.org/10.1016/j.ifset.2012.07.008.

Pojedinec, S. L., Slider, S. D., Kenney, P. B., Head, M. K., Jittinandana, S., \& Henning, W. R. (2011). Carcass maturity and dicationic salts affect preblended, low-fat, low-sodium restructured beef. Meat Science, 88(1), 122-127. http://dx.doi.org/10.1016/j.meatsci.2010.12.012. PMid:21196085.

Rama, R., Chiu, N., Silva, M. C., Hewson, L., Hort, J., \& Fisk, I. D. (2013). Impact of salt crystal size on in-mouth delivery of sodium and saltiness perception from snack foods. Journal of Texture Studies, 44(5), 338-345. http://dx.doi.org/10.1111/jtxs.12017.

Rodrigues, J. F., Gonçalves, C. S., Pereira, R. C., Carneiro, J. D. S., \& Pinheiro, A. C. M. (2014). Utilization of temporal dominance of sensations and time intensity methodology for development of low-sodium Mozzarella cheese using a mixture of salts. Journal of Dairy Science, 97(8), 4733-4744. http://dx.doi.org/10.3168/jds.20147913. PMid:24881790.

Ruusunen, M., \& Puolanne, E. (2005a). Reducing sodium intake from meat products. Meat Science, 70(3), 531-541. http://dx.doi. org/10.1016/j.meatsci.2004.07.016. PMid:22063751.

Ruusunen, M., Vainionpää, J., Lyly, M., Lähteenmäki, L., Niemistö, M., Ahvenainen, R., \& Puolanne, E. (2005b). Reducing the sodium content in meat products: The effect of the formulation in lowsodium ground meat patties. Meat Science, 69(1), 53-60. http:// dx.doi.org/10.1016/j.meatsci.2004.06.005. PMid:22062639.

Saint-Eve, A., Lauverjat, C., Magnan, C., Déléris, I., \& Souchon, I. (2009). Reducing salt and fat content: impact of composition, texture and cognitive interactions on the perception of flavoured model cheeses. Food Chemistry, 116(1), 167-175. http://dx.doi. org/10.1016/j.foodchem.2009.02.027.

Serra, X., Sárraga, C., Grèbol, N., Guàrdia, M. D., Guerrero, L., Gou, P., Masoliver, P., Gassiot, M., Monfort, J. M., \& Arnau, J. (2007). High pressure applied to frozen ham at different process stages. 1. Effect on the final physicochemical parameters and on the antioxidant and proteolytic enzyme activities of dry-cured ham. Meat Science, 75(1), 12-20. http://dx.doi.org/10.1016/j.meatsci.2006.06.009. PMid:22063406.

Speroni, F., Szerman, N., \& Vaudagna, S. R. (2014). High hydrostatic pressure processing of beef patties: Effects of pressure level and sodium tripolyphosphate and sodium chloride concentrations on thermal and aggregative properties of proteins. Innovative Food Science \& Emerging Technologies, 23, 10-17. http://dx.doi. org/10.1016/j.ifset.2014.03.011.

Toldrá, F., \& Reig, M. (2011). Innovations for healthier processed meats. Trends in Food Science \& Technology, 22(9), 517-522. http://dx.doi. org/10.1016/j.tifs.2011.08.007.

Trujillo, A. J., Capellas, M., Saldo, J., Gervilla, R., \& Guamis, B. (2002). Applications of high-hydrostatic pressure on milk and dairy products: a review. Innovative Food Science \& Emerging Technologies, 3(4), 295-307. http://dx.doi.org/10.1016/S1466-8564(02)00049-8.

Vercammen, A., Vanoirbeek, K. G. A., Lurquin, I., Steen, L., Goemaere, O., Szczepaniak, S., Paelinck, H., Hendrickx, M. E. G., \& Michiels, C. W. (2011). Shelf-life extension of cooked ham model product by high hydrostatic pressure and natural preservatives. Innovative Food Science \& Emerging Technologies, 12(4), 407-415. http://dx.doi. org/10.1016/j.ifset.2011.07.009.

Villamonte, G., Simonin, H., Duranton, F., Chéret, R., \& de Lamballerie, M. (2013). Functionality of pork meat proteins: impact of sodium chloride and phosphates under high-pressure processing. Innovative Food Science \& Emerging Technologies, 18, 15-23. http://dx.doi. org/10.1016/j.ifset.2012.12.001.

Voigt, D. D., Chevalier, F., Donaghy, J. A., Patterson, M. F., Qian, M. C., \& Kelly, A. L. (2012). Effect of high-pressure treatment of milk for cheese manufacture on proteolysis, lipolysis, texture and functionality of Cheddar cheese during ripening. Innovative Food Science \& Emerging Technologies, 13, 23-30. http://dx.doi. org/10.1016/j.ifset.2011.10.004.

Wallis, K., \& Chapman, S. (2012). Food and health innovation service. Current innovations in reducing salt in food products. Gloucestershire: Campden BRI. Retrieved from http://www.foodhealthinnovation. com/media/4078/salt_reduction_2012.pdf

Wang, C.-Y., Huang, H.-W., Hsu, C.-P., \& Yang, B. B. (2015). Recent advances in food processing using high hydrostatic pressure technology. Critical Reviews in Food Science and Nutrition. http:// dx.doi.org/10.1080/10408398.2012.745479

World Health Organization - WHO. (2011). Review and updating of current WHO recommendations on salt/sodium and potassium consumption. Genebra: World Health Organization. Retrieved from http://www.who.int/nutrition/events/NUGAG_dietandhealth_ subgroup_call_public_comment_scope_of_Na_K.pdf

Wu, H., Zhang, Y., Long, M., Tang, J., Yu, X., Wang, J., \& Zhang, J. (2014). Proteolysis and sensory properties of dry-cured bacon as affected by the partial substitution of sodium chloride with potassium chloride. Meat Science, 96(3), 1325-1331. http://dx.doi.org/10.1016/j. meatsci.2013.10.037. PMid:24342182.

Wyness, L. A., Butriss, J. L., \& Stanner, S. A. (2012). Reducing the population's sodium intake: the UK Food Standards Agency's salt reduction programme. Public Health Nutrition, 15(2), 254-261. http://dx.doi.org/10.1017/S1368980011000966. PMid:21729460. 
Zamora, A., Ferragut, V., Quevedo, J. M., Guamis, B., \& Trujillo, A.-J. (2012). Ultra-high pressure homogenisation of milk: technological aspects of cheese-making and microbial shelf life of a starter-free fresh cheese. Journal of Dairy Research, 79(2), 168-175. http://dx.doi. org/doi:10.1017/S0022029912000052
Zanardi, E., Ghidini, S., Conter, M., \& Ianieri, A. (2010). Mineral composition of Italian salami and effect of $\mathrm{NaCl}$ partial replacement on compositional, physico-chemical and sensory parameters. Meat Science, 86(3), 742-747. http://dx.doi.org/10.1016/j.meatsci.2010.06.015. PMid:20663614. 